\title{
KUALITAS DIET DAN AKTIVITAS FISIK PADA REMAJA OBESITAS DAN NON OBESITAS
}

\author{
Garnis Retnaningrum, Fillah Fithra Dieny ${ }^{*}$ \\ Program Studi Ilmu Gizi Fakultas Kedokteran Universitas Diponegoro \\ J1.Dr.Sutomo No.18, Semarang, Telp (024) 8453708, Email : gizifk@ undip.ac.id
}

\begin{abstract}
Background: Obesity in adolescents was caused by low diet quality which described through inappropriate food consumption compared to recommendation, while physical activity (energy output) was very minimal.

Objective: This study aimed to analyze affect of diet quality and physical activity with obesity status in adolescents. Method: Observational study used case control design with 112 subjects at junior high school Nasima, Al Azhar 14, and 23 Semarang. The subjects in this study was conducted 56 obese and 56 non obese adolescents aged 13-15 years old, which selected by proportional random sampling with matching in gender and origin of school. Data on identity subjects, fat body percentage, diet quality, and physical activity. Fat body percentage was measured by Bioelectrical Impedance Analysis (BIA), diet quality was obtained by Diet Quality index-International (DQI-I) form and physical activity was obtained by International Physical Activity Questionnaire-short form (IPAQ-short form) survey. Chi square test was used to analyze association between diet quality, physical activity, and obesity status. Logistic regression test was used to analyze the most common variable that caused the obesity.

Result: Mostly obese (96.4\%) and non obese (64.3\%) adolescents had low diet quality. Low diet quality in non obese adolescents were caused by lack of fiber and micronutrient consumption, high intake of saturated fatty acid, and imbalance proportion of macronutrient and fatty acid, while in obese adolescents added with excessive energy, carbohydrat, fat, cholesterol, and food with low nutrient density intake. About $73.2 \%$ obesity had low physical activity than non-obesity which only $23.2 \%$. Low diet quality and lack of physical activity both had risk at 10.4 and 7.2 more to had obesity.
\end{abstract}

Conclusion: Low diet quality and lack of physical activity affected to obesity status in adolescents

Keywords: Diet quality, obesity, physical activity, adolescents

\section{ABSTRAK}

Latar Belakang: Obesitas pada remaja disebabkan oleh rendahnya kualitas diet yang digambarkan melalui asupan makanan yang tidak sesuai dengan rekomendasi, sedangkan aktivitas fisik (pengeluaran energi) sangat minimal.

Tujuan: menganalisis pengaruh kualitas diet dan aktivitas fisik terhadap status obesitas remaja.

Metode: Penelitian observasional dengan pendekatan case control melibatkan 112 subjek di SMP Nasima, SMP Al Azhar 14, dan 23 Semarang. Subjek terdiri dari 56 remaja obesitas dan 56 remaja non obesitas usia 13-15 tahun yang dipilih melalui proportional random sampling dan dilakukan matching terhadap jenis kelamin dan asal sekolah. Data yang dikumpulkan meliputi identitas sampel, persen lemak tubuh, kualitas diet, dan aktivitas fisik. Persen lemak tubuh diukur menggunakan Bioelectrical Impedance Analysis (BIA), kualitas diet diperoleh melalui formulir Diet Quality Index- International (DQI-I), dan aktivitas fisik menggunakan kuesioner International Physical Activity Questionnaire-short form (IPAQ-short form). Uji chi square untuk menganalisis hubungan kualitas diet dan aktivitas fisik terhadap status obesitas. Uji regresi logistik untuk menganalisis variabel yang paling berpengaruh terhadap status obesitas.

Hasil: Sebagian besar remaja obesitas (96.4\%) dan non obesitas (64.3\%) memiliki kualitas diet rendah. Kualitas diet rendah pada remaja non obesitas digambarkan dengan rendahnya asupan serat dan mikronutrien, tingginya asupan lemak jenuh dan adanya ketidakseimbangan proporsi makronutrien dan asam lemak, sementara pada remaja obesitas ditambah dengan tingginya asupan energi, karbohidrat, lemak, kolestrol, dan makanan rendah zat gizi. Sebanyak $73.2 \%$ remaja obesitas juga memiliki aktivitas fisik yang rendah, sementara remaja non obesitas yang memiliki aktivitas fisik rendah hanya 23.2\%. Remaja dengan kualitas diet rendah dan aktivitas fisik rendah masing-masing memiliki risiko 10.4 dan 7.2 kali lebih besar untuk mengalami obesitas.

Simpulan: Kualitas diet yang rendah dan aktivitas fisik yang rendah berpengaruh terhadap status obesitas pada remaja.

Kata Kunci: kualitas diet, obesitas, aktivitas fisik, remaja

\section{PENDAHULUAN}

Remaja membutuhkan asupan zat gizi yang lebih besar daripada masa anak-anak, namun pada kenyataannya remaja cenderung melakukan perilaku makan yang salah yaitu zat gizi yang diasup tidak sesuai dengan kebutuhan atau rekomendasi diet yang dianjurkan. ${ }^{1.2}$ Perilaku makan yang salah dapat menyebabkan munculnya masalah gizi. ${ }^{2}$ 
Gizi lebih merupakan masalah gizi yang saat ini prevalensinya terus mengalami peningkatan yang lebih tajam dari tahun ke tahun. Data dari Riskesdas 2013 menunjukkan prevalensi remaja gemuk usia 13-15 tahun meningkat dari 2,5\% pada tahun 2010 menjadi $10,8 \%$ pada tahun 2013 yang terdiri dari $8,3 \%$ overweight dan $2,5 \%$ obesitas. ${ }^{3,4}$ Riskesdas Jawa Tengah tahun 2013 pun menunjukkan prevalensi obesitas pada remaja usia 13-15 tahun mencapai $2,4 \% .^{5}$

Obesitas disebabkan adanya keseimbangan energi positif, yaitu ketidakseimbangan antara energi yang masuk dengan energi yang keluar dimana jumlah asupan energi berlebihan namun aktivitas fisik yang digunakan untuk pengeluaran energi sangat minimal, sehingga terjadi kelebihan energi yang disimpan dalam bentuk jaringan lemak. ${ }^{6,7}$ Penelitian terhadap remaja di Amerika mendapatkan hubungan antara aktivitas fisik yang rendah dengan kejadian obesitas. Remaja dengan aktivitas fisik yang rendah mempunyai risiko peningkatan berat badan sebesar $\geq 5 \mathrm{~kg}$ dalam rentang satu tahun. Selain itu, remaja yang menonton $\mathrm{TV} \geq 5$ jam perhari mempunyai risiko obesitas sebesar 5,3 kali lebih besar dibanding mereka yang menonton $\mathrm{TV} \leq 2$ jam setiap harinya. ${ }^{8}$ Kurangnya aktivitas fisik inilah yang menjadi salah satu pemicu terjadinya obesitas karena sedikitnya energi yang dipergunakan. ${ }^{7}$

Faktor lain selain aktivitas fisik yaitu ketidaksesuaian pemenuhan zat gizi seperti asupan energi yang berlebihan tidak hanya memberikan pengaruh terhadap status gizinya, tetapi juga memberikan pengaruh terhadap kualitas dietnya. ${ }^{9}$ Kualitas diet menunjukkan apakah asupan makanan telah sesuai dengan rekomendasi. Kualitas diet dan status gizi saling berhubungan karena asupan yang tidak sesuai rekomendasi akan mempengaruhi status gizinya. ${ }^{10}$ Penelitian di Inggris tahun 2009 menunjukkan mereka yang memiliki Indeks Massa Tubuh (IMT) tinggi (overweight dan obesitas) memiliki kualitas diet yang lebih rendah dibanding dengan yang memiliki IMT normal. ${ }^{9}$

Kualitas diet mencakup empat kategori utama, yaitu variasi, kecukupan, moderasi, dan keseimbangan keseluruhan dari diet. ${ }^{10}$ Kualitas diet yang tinggi dikaitkan dengan konsumsi makanan yang mencukupi kebutuhan makronutrien secara tepat, tidak kurang maupun lebih dan asupan mikronutrien yang mencukupi kebutuhan. Kualitas diet yang rendah dikaitkan dengan konsumsi makanan yang tinggi energi dan lemak, serta rendah serat dan mikronutrien. ${ }^{11}$

Perilaku makan pada sebagian besar kelompok obesitas di US tahun 2008 yang mendukung rendahnya kualitas diet ditunjukkan dengan frekuensi konsumsi pangan, makanan cepat saji, minuman soda, dan kudapan yang memiliki densitas energi tinggi lebih tinggi daripada kelompok non obesitas. ${ }^{12}$ Konsumsi makanan cepat saji berkaitan dengan mereka yang mengalami masalah obesitas karena makanan cepat saji cenderung padat energi, rendah mikronutrien, rendah serat sehingga berkontribusi terhadap gizi lebih dan obesitas. ${ }^{13}$ Penelitian di US tahun 2001 juga menunjukkan bahwa terdapat hubungan yang signifikan antara konsumsi makanan cepat saji dengan peningkatan asupan energi dan asupan lemak. ${ }^{14}$ Penelitian lain yang melibatkan anak-anak dan remaja di negara yang sama tahun 2004 juga menunjukkan hal serupa yaitu remaja yang mengkonsumsi makanan cepat saji memiliki total asupan energi, lemak, karbohidrat lebih tinggi dibandingkan dengan yang tidak mengkonsumsi makanan cepat saji. Selain itu, asupan serat mereka cenderung rendah, dan kurang konsumsi buah serta sayuran. ${ }^{15}$ Konsumsi minuman soda juga dapat memepengaruhi kualitas diet karena berpengaruh terhadap total asupan energi. ${ }^{16}$ Hal tersebut didukung penelitian yang dilakukan di US bahwa peningkatan konsumsi minuman soda berkorelasi positif dengan peningkatan asupan energi dan kejadian obesitas secara bersamaan pada remaja. ${ }^{17}$

Dilihat dari segi kuantitas, sebagian besar kelompok obesitas memiliki tingkat konsumsi energi, karbohidrat, protein, dan lemak lebih tinggi daripada kelompok non obesitas. Penelitian yang dilakukan di Malaysia tahun 2006 menunjukkan remaja dengan kelompok obesitas memiliki asupan lemak lebih dari $30 \% .{ }^{18}$ Penelitian tersebut sejalan dengan penelitian yang dilakukan terhadap remaja di Surabaya tahun 2012 yang menunjukkan sebanyak $90 \%$ remaja yang termasuk dalam kelompok obesitas memiliki tingkat konsumsi lemak lebih dari $20 \%, 85 \%$ memiliki tingkat konsumsi karbohidrat lebih dari $60 \%$ dan $45 \%$ remaja obesitas memiliki tingkat konsumsi protein lebih dari $20 \% .^{12}$

Berdasarkan penelitian pendahuluan pada siswa kelas VII dan VIII SMP Nasima, SMP Al Azhar 14, dan 23 Semarang ditemukan angka prevalensi obesitas masing-masing sebesar $13.16 \%$ ; $10.3 \%$; 8.26\%. Hasil ini cukup tinggi dibandingkan dengan prevalensi obesitas di Indonesia dan Jawa Tengah. Lokasinya yang terletak di daerah perkotaan membuat akses menuju pusat perbelanjaan dan restoran cepat saji lebih mudah sehingga mendorong remaja untuk mengkonsumsi makanan yang tinggi energi, lemak jenuh dan rendah serat. Berdasarkan latar belakang 
tersebut, peneliti ingin menganalisis pengaruh kualitas diet dan aktivitas fisik terhadap status obesitas remaja.

\section{METODE PENELITIAN}

Penelitian ini dilaksanakan di SMP Nasima, SMP Islam Al Azhar 14, dan 23 Semarang pada bulan April-Mei 2015. Penelitian ini termasuk lingkup gizi masyarakat dan merupakan studi observasional dengan desain case control.

Populasi pada penelitian ini adalah seluruh siswa kelas VII dan VIII dari ketiga sekolah tersebut sejumlah 582 siswa. Pengambilan subjek diawali dengan melakukan skrining terhadap seluruh siswa untuk mengkategorikankan status gizi berdasarkan persen lemak tubuh. Siswa yang memiliki persen lemak tubuh dengan persentil $>95$ dikategorikankan obesitas dan yang memiliki persentil 2-85 dikategorikan non obesitas. Selanjutnya, subjek diambil dengan cara proportional random sampling untuk mendapatkan 56 subjek pada masing-masing kelompok sehingga total subjek dalam penelitian ini berjumlah 112 subjek. Subjek obesitas dimasukkan dalam kelompok kasus, sementara subjek non obesitas dimasukkan dalam kelompok kontrol. Pemilihan kelompok kontrol diambil dengan cara matching by design. Variabel yang di matching yaitu kelompok jenis kelamin dan asal sekolah.

Data yang dikumpulkan dalam penelitian ini adalah identitas subjek, persen lemak tubuh, kualitas diet, dan aktivitas fisik. Kualitas diet adalah penilaian konsumsi makanan yang terdiri dari 4 kategori utama yaitu variasi, kecukupan, moderasi, dan keseimbangan keseluruhan berdasarkan rekomendasi diet atau pedoman gizi dengan menggunakan formulir DQI-I (Diet Quality Indexs International). Total nilai dalam DQI-I bisa bervariasi mulai dari 0 sampai 100 (0 adalah skor terendah dan 100 merupakan skor tertinggi). Kualitas diet dinilai rendah jika skor $\leq 60 \%$ dan kualitas diet dinilai tinggi jika skor $>60 \% .^{19,20}$

Aktivitas fisik adalah setiap gerakan tubuh yang dihasilkan oleh otot rangka yang memerlukan pengeluaran energi. ${ }^{21}$ Pengukuran aktivitas fisik menggunakan kuesioner International Physical Activity Questionnaire (IPAQ)-short form. Aktivitas fisik digolongkan kedalam 3 komponen, yaitu komponen rendah, sedang, dan tinggi. Komponen tinggi jika aktivitas fisik berat dilakukan setidaknya 3 hari dan minimal MET 1500 MET menit/minggu atau 7 hari atau lebih kombinasi aktivitas berjalan kaki dan aktivitas fisik sedang atau aktivitas berjalan kaki dan aktivitas fisik berat dan menghasilkan setidaknya 3000 METmenit/minggu. Komponen sedang jika 3 hari atau lebih seseorang melakukan aktivitas fisik berat minimal 20 menit/hari, atau 5 hari atau lebih seseorang dalam melakukan aktivitas fisik sedang/ aktivitas berjalan minimal 30 menit/hari atau 5 hari atau lebih kombinasi dari aktivitas berjalan, aktivitas fisik sedang dan aktivitas fisik berat mencapai total MET minimal 600 METmenit/minggu. Komponen rendah jika total aktivitas fisik seseorang tidak mencakup komponen tinggi atau sedang. ${ }^{22}$

Pengolahan dan analisis data dilakukan dengan program komputer. Analisis univariat untuk mendeskripsikan kategori, rerata, standar deviasi, nilai minimal dan maksimal semua variabel yang diambil. Analisis bivariat digunakan untuk menganalisis perbedaan skor kualitas diet dan aktivitas fisik sebagai variabel perancu antara kedua kelompok serta menganalisis hubungan kualitas diet dan aktivitas fisik terhadap status obesitas. Analisis bivariat diawali dengan uji kenormalan data dengan menggunakan uji Kolmogorov Smirnov. Uji independent $t$ test digunakan untuk menganalisis perbedaan skor kualitas diet karena data berdistribusi normal, sementara uji Mann Whitney digunakan untuk menganalisis perbedaan skor aktivitas fisik karena data berdistribusi tidak normal. Uji bivariat dengan chi square untuk menganalisis hubungan kualitas diet dan aktivitas fisik terhadap status obesitas serta analisis multivariat dengan regresi logistik dilakukan untuk mengetahui variabel yang paling berpengaruh terhadap status obesitas.

\section{HASIL PENELITIAN}

Total subjek pada penelitian ini sebanyak 112 yang terdiri dari 56 remaja obesitas dan 56 remaja non obesitas usia 13-15 tahun. Subjek terdiri dari 11 siswa perempuan (19.64\%) dan 45 siswa laki-laki $(80.36 \%)$ pada masing-masing kelompok. Kelompok obesitas memiliki persen lemak tubuh $25.5 \%$ hingga $50 \%$ dengan rerata $34.96 \% \pm 6.27$, sementara kelompok non obesitas memiliki persen lemak tubuh $11.9 \%$ hingga $28 \%$ dengan rerata $17.01 \% \pm 3.59$.

\section{Kualitas Diet}

Berdasarkan tabel 1, rerata skor kualitas diet pada obesitas yaitu 48.36 \pm 7.24 sedangkan pada non obesitas yaitu 57.21 \pm 7.76 . Keduanya memiliki rerata yang menunjukkan kualitas diet rendah, walaupun secara statistik menunjukkan adanya perbedaan antara skor kualitas diet remaja obesitas dan non obesitas $(p=0.000)$. Remaja obesitas yang memiliki kualitas diet rendah sebanyak $96.4 \%$ dan dari kelompok non 
obesitas sebanyak $64.3 \%$. Kualitas diet rendah diartikan bahwa asupan makanannya belum sesuai dengan rekomendasi. Berdasarkan uji chi square $(p=0.000)$, dapat disimpulkan bahwa terdapat hubungan kualitas diet terhadap status obesitas pada remaja. Kualitas diet antara remaja obesitas dan non obesitas dapat dilihat pada tabel 2.

Tabel 1. Karakteristik Subjek Penelitian antara Kelompok Obesitas dan Non Obesitas

\begin{tabular}{|c|c|c|c|c|c|c|c|}
\hline \multirow[t]{2}{*}{ Karakteristik Subjek } & \multicolumn{3}{|c|}{ Obesitas $(n=56)$} & \multicolumn{3}{|c|}{ Non Obesitas $(n=56)$} & \multirow[b]{2}{*}{$n$} \\
\hline & Min & Max & Rerata \pm SD & Min & Max & Rerata \pm SD & \\
\hline Usia (tahun) & 13.02 & 14.73 & $13.84 \pm 0.44$ & 13.05 & 14.93 & $13.88 \pm 0.48$ & \\
\hline Persen lemak tubuh $(\%)$ & 25.5 & 50 & $34.96 \pm 6.27$ & 11.9 & 28 & $17.01 \pm 3.59$ & $0.000 *(\mathrm{~S})$ \\
\hline Kualitas diet (skor DQI-I) & 33 & 68 & $48.36 \pm 7.24$ & 38 & 73 & $57.21 \pm 7.76$ & $0.000 *(\mathrm{~S})$ \\
\hline Skor aktivitas fisik (MET- & 40 & 3219 & $556.04 \pm 471.89$ & 49.5 & 3988.5 & $1155.49 \pm 792.91$ & $0.000 * *(\mathrm{~S})$ \\
\hline
\end{tabular}
min-minggu)

*Independent $t$ test

**Mann-Whitney

Tabel 2. Hubungan kualitas diet dengan status obesitas

\begin{tabular}{|c|c|c|c|c|c|c|}
\hline & & \multicolumn{4}{|c|}{ Status Obesitas } & \multirow{3}{*}{$p$} \\
\hline & & \multicolumn{2}{|c|}{ Obesitas } & \multicolumn{2}{|c|}{ Non Obesitas } & \\
\hline & & $\mathrm{n}$ & $\%$ & $\mathrm{n}$ & $\%$ & \\
\hline \multirow[t]{2}{*}{ Kualitas Diet } & Rendah & 54 & 96.4 & 36 & 64.3 & $0.000 *(\mathrm{~S})$ \\
\hline & Tinggi & 2 & 3.6 & 20 & 35.7 & \\
\hline Total & & 56 & 100.0 & 56 & 100.0 & \\
\hline
\end{tabular}

Kualitas diet terdiri dari empat kategori, yaitu variasi, kecukupan, moderasi, dan keseimbangan keseluruhan. Kategori kualitas diet yang menunjukkan perbedaan antara kelompok obesitas dan non obesitas adalah moderasi dan keseimbangan keseluruhan $(p=0.000 ; p=0.000)$, sedangkan kategori variasi dan kecukupan menunjukkan tidak ada perbedaan signifikan antara kelompok obesitas dan non obesitas $(p=0.209$; $p=0.934)$.

Tabel 3. Perbedaan Kategori Kualitas Diet antara Kelompok Obesitas dan Non Obesitas

\begin{tabular}{|c|c|c|c|c|c|c|c|}
\hline \multirow{2}{*}{ Kategori } & \multicolumn{3}{|c|}{ Obesitas $(n=64)$} & \multicolumn{3}{|c|}{ Non Obesitas $(n=64)$} & \multirow[b]{2}{*}{$p$} \\
\hline & Min & Max & Rerata \pm SD & Min & Max & Rerata \pm SD & \\
\hline Variasi (skor) & 10 & 20 & $15.88 \pm 2.95$ & 10 & 20 & $16.57 \pm 2.61$ & $0.209 * *(\mathrm{NS})$ \\
\hline Keseluruhan & 3 & 5 & $3.95 \pm 0.74$ & 3 & 5 & $4.21 \pm 0.75$ & $0.061 * *(\mathrm{NS})$ \\
\hline Sumber protein & 1 & 4 & $2.77 \pm 0.85$ & 1 & 4 & $2.63 \pm 0.75$ & $0.432 * *(\mathrm{NS})$ \\
\hline Kecukupan (skor) & 14 & 38 & $25.07 \pm 5.49$ & 14 & 36 & $24.98 \pm 5.84$ & $0.934 *(\mathrm{NS})$ \\
\hline Kelompok sayuran & 0 & 3.6 & $0.83 \pm 0.69$ & 0.04 & 2.8 & $0.9 \pm 0.61$ & $0.362 * *(\mathrm{NS})$ \\
\hline Kelompok buah & 0.2 & 6 & $1.8 \pm 1.49$ & 0.01 & 6.3 & $1.78 \pm 1.26$ & $0.604 * *(\mathrm{NS})$ \\
\hline $\begin{array}{l}\text { Kelompok makanan } \\
\text { pokok }\end{array}$ & 2.6 & 11.3 & $6.81 \pm 1.47$ & 3.2 & 11.6 & $5.75 \pm 1.51$ & $0.000 *(\mathrm{~S})$ \\
\hline Serat & 8 & 41.3 & $14.09 \pm 6.48$ & 4 & 25.7 & $16.76 \pm 33.11$ & $0.018 * *(\mathrm{~S})$ \\
\hline Ptotein & 9.3 & 33.7 & $15.39 \pm 4.83$ & 4.4 & 26.5 & $13.56 \pm 3.57$ & $0.024 *(\mathrm{~S})$ \\
\hline Besi & 6.7 & 127 & $17.84 \pm 21.46$ & 3.7 & 81.4 & $16.47 \pm 13.31$ & $0.800 * *(\mathrm{NS})$ \\
\hline Kalsium & 174.5 & 2319.2 & $682.96 \pm 403.52$ & 249.5 & 1495.4 & $661.79 \pm 295.96$ & $0.751 * *(\mathrm{NS})$ \\
\hline Vitamin C & 28 & 321.7 & $113.75 \pm 65.01$ & 17.6 & 371.2 & $96.39 \pm 66.33$ & $0.061 * *(\mathrm{NS})$ \\
\hline Moderasi (skor) & 0 & 15 & $7.5 \pm 3.75$ & 6 & 27 & $14.73 \pm 5.09$ & $0.000^{* *(\mathrm{~S})}$ \\
\hline Total lemak & 29 & 60.5 & $39.78 \pm 6.03$ & 17.3 & 46.2 & $31.88 \pm 7.31$ & $000 * *(\mathrm{~S})$ \\
\hline Lemak jenuh & 13.2 & 28.1 & $19.38 \pm 3.37$ & 8.7 & 34.5 & $16.38 \pm 3.96$ & $0.000 *(\mathrm{~S})$ \\
\hline Kolestrol & 156.1 & 1084.4 & $402.55 \pm 207.44$ & 110.7 & 688.7 & $321.54 \pm 136.5$ & $0.000 *(\mathrm{~S})$ \\
\hline Natrium & 904 & 3544.9 & $2042.82 \pm 604.86$ & 405.3 & 2598 & $1103.84 \pm 584.92$ & $0.029 * *(\mathrm{~S})$ \\
\hline $\begin{array}{l}\text { Makanan rendah zat } \\
\text { gizi }\end{array}$ & 5.8 & 29.6 & $13.79 \pm 3.36$ & 1.1 & 35.8 & $6.54 \pm 5.02$ & $0.000 * *(\mathrm{~S})$ \\
\hline $\begin{array}{l}\text { Keseimbangan } \\
\text { keseluruhan (skor) }\end{array}$ & 0 & 2 & $0.17 \pm 0.57$ & 0 & 6 & $1.07 \pm 1.47$ & $0.000 * *(\mathrm{~S})$ \\
\hline Rasio makronutrien & 0 & 2 & $0.17 \pm 0.57$ & 0 & 6 & $1.07 \pm 1.47$ & $0.000 * *(\mathrm{~S})$ \\
\hline
\end{tabular}


Kategori variasi dievaluasi dengan dengan dua cara, yaitu secara keseluruhan dan berbagai jenis makanan yang termasuk dalam sumber protein. Kategori ini digunakan untuk menilai apakah asupan berasal dari sumber yang berbeda. Hasil penelitian ini menunjukkan tidak ada perbedaan variasi secara keseluruhan maupun sumber protein antara kelompok obesitas dan non obesitas $(p=0.061 ; p=0.432)$. Kedua kelompok sama-sama memiliki skor variasi makanan yang tidak jauh berbeda karena makanan yang diasup sama-sama bervariasi baik secara keseluruhan maupun dari sumber protein.

Tabel 4. Gambaran Kategori Kecukupan antara Kelompok Obesitas dan Non Obesitas

\begin{tabular}{|c|c|c|c|c|c|}
\hline \multirow{2}{*}{ Variabel } & \multirow{2}{*}{ Komponen } & \multicolumn{2}{|c|}{$\begin{array}{c}\text { Obesitas } \\
(n=56)\end{array}$} & \multicolumn{2}{|c|}{$\begin{array}{c}\text { Non Obesitas } \\
(n=56)\end{array}$} \\
\hline & & $\mathbf{n}$ & $\%$ & $\mathbf{n}$ & $\%$ \\
\hline \multicolumn{6}{|l|}{ Kecukupan } \\
\hline \multirow{3}{*}{ Kelompok sayuran } & Baik ( $\geq 3-5$ sajian/hari) & 2 & 3.6 & 0 & 0 \\
\hline & Cukup $(<3-1.5$ sajian/hari) & 4 & 7.1 & 7 & 12.5 \\
\hline & Kurang (< 1.5 sajian/hari) & 50 & 89.3 & 49 & 87.5 \\
\hline \multirow[t]{3}{*}{ Kelompok buah } & Baik ( $\geq 2-3$ sajian/hari) & 21 & 37.5 & 11 & 19.6 \\
\hline & Cukup (<2-1 sajian/hari) & 17 & 30.4 & 25 & 44.5 \\
\hline & Kurang (< 1 sajian/hari) & 18 & 32.1 & 20 & 35.7 \\
\hline \multirow{2}{*}{ Kelompok makanan pokok } & Baik ( $\geq 3-5$ sajian/hari) & 55 & 98.2 & 56 & 100 \\
\hline & Cukup $(<3-1.5$ sajian/hari) & 1 & 1.8 & 0 & 0 \\
\hline \multirow{3}{*}{ Serat } & Baik ( $\geq 20-30$ g/hari) & 8 & 14.2 & 7 & 12.5 \\
\hline & Cukup $(<20-10 \mathrm{~g} /$ hari $)$ & 38 & 67.9 & 27 & 48.2 \\
\hline & Kurang (< 10 gr/hari $)$ & 10 & 17.9 & 22 & 39.3 \\
\hline \multirow[t]{3}{*}{ Protein } & Baik ( $\geq 15 \%$ energi/hari) & 25 & 44.6 & 19 & 33.9 \\
\hline & Cukup $(<15 \%-7.5$ energi/hari) & 31 & 55.4 & 36 & 64.3 \\
\hline & Kurang ( $<7.5 \%$ energi/hari) & 0 & 0 & 1 & 1.8 \\
\hline \multirow[t]{3}{*}{ Besi } & Baik ( $\geq 100 \%$ RDA mg/hari) & 10 & 17.9 & 11 & 19.6 \\
\hline & Cukup $(<100-50 \%$ RDA mg/hari) & 33 & 58.9 & 35 & 62.5 \\
\hline & Kurang (<50\% RDA mg/hari) & 13 & 23.2 & 10 & 17.9 \\
\hline \multirow[t]{3}{*}{ Kalsium } & Baik ( $\geq 100 \%$ RDA mg/hari) & 5 & 8.9 & 4 & 7.1 \\
\hline & Cukup $(<100-50 \%$ RDA mg/hari) & 24 & 42.9 & 20 & 35.7 \\
\hline & Kurang (<50\% RDA mg/hari) & 27 & 48.2 & 32 & 57.2 \\
\hline \multirow[t]{3}{*}{ Vitamin C } & Baik ( $\geq 100 \%$ RDA mg/hari) & 38 & 67.9 & 27 & 48.2 \\
\hline & Cukup $(<100-50 \%$ RDA mg/hari) & 16 & 28.6 & 24 & 42.9 \\
\hline & Kurang (<50\% RDA mg/hari) & 2 & 3.5 & 5 & 8.9 \\
\hline
\end{tabular}

Tabel 5. Gambaran Kategori Moderasi antara Kelompok Obesitas dan Non Obesitas

\begin{tabular}{|c|c|c|c|c|c|}
\hline \multirow[t]{2}{*}{ Variabel } & \multirow[t]{2}{*}{ Komponen } & \multicolumn{2}{|c|}{$\begin{array}{c}\text { Obesitas } \\
(n=56)\end{array}$} & \multicolumn{2}{|c|}{$\begin{array}{c}\text { Non Obesitas } \\
(n=56)\end{array}$} \\
\hline & & $\mathbf{n}$ & $\%$ & $\mathbf{n}$ & $\%$ \\
\hline \multirow[t]{2}{*}{ Total lemak } & Baik $(\leq 30 \%$ total energi/hari) & 1 & 1.8 & 29 & 51.8 \\
\hline & Lebih (> 30\% total energi/hari) & 55 & 98.2 & 27 & 48.2 \\
\hline \multirow{2}{*}{ Lemak jenuh } & Baik ( $\leq 10 \%$ total energi/hari) & 0 & 0 & 4 & 7.1 \\
\hline & Lebih (> 10\% total energi/hari) & 56 & 100 & 52 & 92.9 \\
\hline \multirow[t]{2}{*}{ Kolestrol } & Baik $(\leq 300 \mathrm{mg} /$ hari $)$ & 18 & 32.1 & 29 & 51.8 \\
\hline & Lebih (> 300 mg/hari) & 37 & 67.9 & 27 & 48.2 \\
\hline \multirow[t]{2}{*}{ Natrium } & Baik ( $\leq 2400 \mathrm{mg} / \mathrm{hari})$ & 33 & 58.9 & 52 & 92.9 \\
\hline & Lebih (> 2400 mg/hari) & 22 & 41.1 & 4 & 7.1 \\
\hline Makanan & Baik $(\leq 10 \%$ total energi/hari) & 1 & 1.8 & 51 & 91.1 \\
\hline rendah zat gizi & Lebih (> 10\% total energi/hari) & 55 & 98.2 & 5 & 8.9 \\
\hline
\end{tabular}

Kategori kecukupan terdiri dari komponen kelompok sayuran, buah, makanan pokok, serat, protein, besi, kalsium, dan vitamin C. Kategori ini mengevaluasi unsur-unsur asupan makanan yang seharusnya tersedia dalam jumlah yang cukup. Hasil penelitian pada komponen di kategori kecukupan menunjukkan adanya perbedaan signifikan antara kelompok obesitas dan non obesitas pada komponen kelompok makanan pokok, serat, dan protein $(p=0.000 ; p=0.018$; $p=0.024)$. Ketiga zat gizi tersebut merupakan zat gizi yang berperan dalam kejadian obesitas. Jika 
dilihat dari kategori pemenuhan, secara keseluruhan asupan makanan kelompok sayuran, buah, serat, besi, dan kalsium pada remaja kelompok obesitas dan non obesitas sama-sama rendah atau kurang dari kebutuhan sehingga memberikan pengaruh terhadap rendahnya kualitas diet remaja pada kedua kelompok, namun remaja obesitas memiliki total asupan yang lebih tinggi (tabel 4) dibandingkan dengan remaja non obesitas sehingga kategori ini lebih berpengaruh terhadap rendahnya kualitas diet pada remaja non obesitas.

Kategori moderasi mengevaluasi asupan makanan dan zat gizi yang berhubungan dengan penyakit kronis dan perlu dibatasi yang terdiri dari total lemak, lemak jenuh, kolestrol, natrium, dan makanan rendah zat gizi. Hasil penelitian ini menunjukkan adanya perbedaan antara kelompok obesitas dan non obesitas pada seluruh komponen moderasi $(p=0.000 ; p=0.000 ; p=0.029 ; p=0.000$; $p=0.000)$. Kelompok obesitas lebih banyak mengkonsumsi zat gizi yang seharusnya dibatasi dibandingkan dengan kelompok non obesitas, seperti terlihat pada tabel 5 , namun terdapat satu komponen yang memiliki asupan sama-sama tinggi pada kedua kelompok yaitu lemak jenuh yang menjadi pemicu rendahnya kualitas diet, tidak hanya pada kelompok obesitas namun juga pada kelompok non obesitas. Hasil analisis pada kategori ini menandakan bahwa seluruh komponen dalam kategori moderasi berperan dalam rendahnya kualitas diet kelompok obesitas, sedangkan pada kelompok non obesitas hanya disebabkan oleh lemak jenuh.

Kategori terakhir yaitu keseimbangan keseluruhan merupakan kategori yang menganalisis keseimbangan keseluruhan diet dalam hal proporsionalitas antara sumber-sumber energi dan komposisi asam lemak. Kategori ini terdiri dari rasio makronutrien (karbohidrat : protein : lemak) dan rasio asam lemak (PUFA : MUFA : SFA). Rasio makronutrien menunjukkan adanya perbedaan antara kelompok obesitas dan non obesitas $(p=0.000)$, namun keduanya masih memiliki keseimbangan yang rendah walaupun nilainya lebih baik pada kelompok non obesitas. Hal inilah yang menyebabkan rendahnya kualitas diet pada kedua kelompok, terutama pada kelompok obesitas. Kelompok obesitas memiliki proporsi asupan lemak $>30 \%$ total energi/hari lebih tinggi (98.2\%) daripada kelompok non obesitas $(48.2 \%)$. Begitu juga dengan asupan protein, sebanyak $44.6 \%$ dari kelompok obesitas memiliki asupan protein $>15 \%$, sementara pada kelompok non obesitas hanya $39.3 \%$. Proporsi lemak dan protein yang tinggi akan memberikan pengaruh pada proporsi karbohidrat pada kelompok obesitas sehingga tidak didapatkan keseimbangan yang sesuai dengan rekomendasi antara ketiga makronutrien ini. Sementara pada komponen rasio asam lemak menunjukkan tidak ada perbedaan karena kedua kelompok sama-sama memiliki skor rasio asam lemak yang rendah. Hal ini terjadi karena secara keseluruhan semua subjek memiliki asupan SFA (Saturated Fatty Acid) yang lebih tinggi, yaitu mencapai $>10 \%$ total energi/hari baik pada kelompok obesitas maupun non obesitas dibandingkan asupan PUFA (Poly Unsaturated Fatty Acid) dan MUFA (Mono Unsaturated Fatty Acid), padahal seharusnya MUFA memiliki proporsi yang lebih tinggi dibandingkan PUFA dan SFA.

\section{Aktivitas Fisik}

Tabel 1 pada skor aktivitas fisik menunjukkan bahwa terdapat perbedaan skor aktivitas fisik antara remaja obesitas dan non obesitas $(p=0.000)$, dimana rerata skor aktivitas fisik pada remaja obesitas lebih rendah, yaitu sebesar $556.04 \mathrm{MET} / \mathrm{min} / \mathrm{minggu} \pm$ 471.89, sedangkan pada remaja non obesitas sebesar 1155.49 MET/min/minggu \pm 792.91. Remaja obesitas sebanyak $73.2 \%$ memiliki komponen aktivitas fisik rendah yang artinya gerakan tubuh yang dilakukan sangat minimal baik dari jenisnya maupun intensitasnya. Sementara kelompok remaja non obesitas yang memiliki komponen aktivitas fisik rendah hanya $23.2 \%$.

Hasil analisis chi square antara aktivitas fisik dengan kejadian obesitas dapat dilihat pada tabel 5. Aktivitas fisik berhubungan dengan status obesitas pada remaja yang ditunjukkan dengan nilai $p=0.000$.

Tabel 6. Hubungan aktivitas fisik dengan status obesitas

\begin{tabular}{|c|c|c|c|c|c|c|}
\hline & & \multicolumn{4}{|c|}{ Status Obesitas } & \multirow{3}{*}{$p$} \\
\hline & & \multicolumn{2}{|c|}{ Obesitas } & \multicolumn{2}{|c|}{ Non Obesitas } & \\
\hline & & $\mathrm{n}$ & $\%$ & $\mathrm{n}$ & $\%$ & \\
\hline \multirow{3}{*}{ Aktivitas fisik } & Rendah & 41 & 73.2 & 13 & 23.2 & $0.000 *(\mathrm{~S})$ \\
\hline & Sedang & 13 & 23.2 & 29 & 51.8 & \\
\hline & Tinggi & 2 & 3.6 & 14 & 25 & \\
\hline Total & & 56 & 100.0 & 56 & 100.0 & \\
\hline
\end{tabular}




\section{Pengaruh Kualitas Diet dan Aktivitas Fisik terhadap Status Obesitas}

Uji multivariat dengan regresi logistik dilakukan untuk mengetahui pengaruh yang paling kuat antara kualitas diet dan aktivitas fisik terhadap status obesitas pada remaja.

Tabel 6. Pengaruh kualitas diet dan aktivitas fisik terhadap status obesitas

\begin{tabular}{lccccc}
\hline \multirow{2}{*}{ Variabel } & \multirow{2}{*}{ koefisien } & \multirow{2}{*}{$p$} & OR & \multicolumn{2}{c}{ 95\%CI } \\
\cline { 5 - 6 } \cline { 5 - 6 } & & & & Minimum & maksimum \\
\hline Kualitas diet & 2.34 & 0.004 & 10.38 & 2.1 & 51.24 \\
Aktivitas fisik & 1.981 & 0.000 & 7.25 & 2.93 & 17.92 \\
Konstanta & -1.374 & 0.000 & 0.253 & & \\
*regresi logistik & & & &
\end{tabular}

Hasil uji regresi logistik (tabel 6) dapat dilihat bahwa kualitas diet dan aktivitas fisik merupakan faktor risiko terhadap status obesitas pada remaja. Kualitas diet merupakan variabel yang paling berpengaruh terhadap obesitas yang ditunjukkan dengan OR sebesar 10.38 (95\% CI : 2.1-51.24), sementara aktivitas fisik memiliki nilai OR sebesar 7.25 (95\% CI : 2.93-17.92). Hal ini menunjukkan bahwa remaja dengan kualitas diet rendah memiliki risiko 10.4 kali lebih besar untuk mengalami obesitas dibandingkan dengan remaja dengan kualitas diet yang tinggi. Selain itu, remaja dengan aktivitas fisik yang rendah memiliki risiko 7.2 kali lebih besar untuk mengalami obesitas.

Berdasarkan tabel 6, dapat diperoleh persamaan yaitu y $=-1.374+2.34$ (kualitas diet) + 1.981 (aktivitas fisik). Hasil perhitungan dari persamaan tersebut adalah probabilitas subjek akan mengalami obesitas sebesar $95 \%$ apabila terdapat faktor risiko kualitas diet yang rendah dan aktivitas fisik yang rendah.

\section{PEMBAHASAN}

Hasil penelitian menunjukkan rata-rata skor kualitas diet lebih tinggi pada remaja non obesitas dibanding obesitas, namun sebagian besar remaja pada kedua kelompok memiliki kualitas diet yang rendah. Sebanyak $96.4 \%$ remaja obesitas dan $64.3 \%$ remaja non obesitas memiliki kualitas diet rendah. Rendahnya skor kualitas diet pada kedua kelompok dipengaruhi oleh ketidaksesuaian asupan zat gizi yang terdapat pada kategori kualitas diet.

Kualitas diet terdiri dari empat kategori utama, yaitu variasi, kecukupan, moderasi, dan keseimbangan keseluruhan. Hasil analisis berdasarkan skor masing-masing kategori kualitas diet, skor kategori variasi dan kecukupan tidak menunjukkan adanya perbedaan, namun perbedaan muncul pada kategori moderasi dan keseimbangan keseluruhan. Berdasarkan pemenuhan zat gizinya, beberapa komponen pada kategori kecukupan, moderasi, dan keseimbangan keseluruhan lah yang membuat rendahnya kualitas diet pada kedua kelompok. Kualitas diet yang rendah di kelompok obesitas terutama disebabkan oleh berlebihnya seluruh zat gizi yang ada pada kategori moderasi, kurangnya beberapa zat gizi di kategori kecukupan, dan rendahnya keseimbangan keseluruhan (makronutrien dan asam lemak), sementara pada kelompok non obesitas kategori yang paling berperan dalam rendahnya kualitas diet adalah kecukupan dimana sebagian besar zat gizi yang ada pada kategori kecukupan kurang dari kebutuhan. Kategori moderasi juga berperan dalam rendahnya kualitas diet pada kelompok non obesitas tetapi hanya pada komponen lemak jenuh dan kategori keseimbangan keseluruhan juga ikut berperan baik pada rasio makronutrien maupun asam lemak.

Skor pada kategori kecukupan menunjukkan tidak adanya perbedaan antara kedua kelompok, namun terdapat perbedaan pemenuhan beberapa kelompok makanan dan zat gizi yang menyebabkan rendahnya kualitas diet pada kedua kelompok. Kelompok obesitas hanya memenuhi asupan kelompok makanan pokok, protein, dan vitamin $\mathrm{C}$ sedangkan kelompok non obesitas hanya memenuhi asupan pada kelompok makanan pokok dan vitamin C. Sementara komponen lain dari kategori kecukupan, yaitu asupan sayur, buah, serat, besi, dan kalsium pada kedua kelompok sebagian besar kurang dari kebutuhan. Rendahnya asupan zat gizi yang ada di kategori kecukupan menjadi faktor rendahnya kualitas diet pada kedua kelompok. Asupan serat pada kedua kelompok belum ada yang memenuhi kebutuhan, namun kelompok obesitas memiliki asupan yang lebih rendah dari kelompok non obesitas. Asupan serat yang rendah pada kelompok obesitas dan non obesitas disebabkan rendahnya konsumsi kelompok makanan yang memiliki serat tinggi, seperti sayuran dan buahbuahan. Hasil ini sejalan dengan penelitian Aprianthi (2009) yang menunjukkan bahwa konsumsi serat pada remaja masih kurang dan dapat menjadi faktor risiko terhadap terjadinya obesitas. ${ }^{23}$ Konsumsi serat yang cukup dapat mencegah kejadian obesitas karena serat mengabsorbsi air, 
memperluas penyerapan di usus, dan memperlambat pergerakan makanan pada saluran pencernaan sehingga menimbulkan rasa kenyang yang lebih lama. Selain itu, serat tidak dicerna oleh enzim pencernaan sehingga tidak menghasilkan energi. ${ }^{24}$ Asupan besi dan kalsium pada kedua kelompok juga kurang dari kebutuhan $(26 \mathrm{mg} ; 1200$ $\mu \mathrm{g})$. Hal ini disebabkan oleh pemilihan makanan dan kebiasaan jajan dari remaja itu sendiri. Mereka lebih banyak mengkonsumsi makanan yang tinggi energi, lemak, natrium serta rendah vitamin dan mineral, yaitu fastfood seperti fried chiken, french fries, hamburger, beef steak, spaghetti dan pizza. Protein menjadi zat gizi yang pemenuhannya berbeda antara kedua kelompok ini. Secara statistik protein juga menunjukkan adanya perbedaan yang signifikan antara kelompok obesitas dan non obesitas. Hal ini terjadi karena remaja obesitas lebih banyak mengkonsumsi sumber protein hewani (bersumber dari daging dan unggas) $\geq 2-3$ kali sajian/hari dengan total asupan protein $\geq 15 \%$ dari total energi/hari. Asupan protein memiliki hubungan langsung dengan obesitas. Jumlah protein yang berlebihan akan mengalami deaminase atau melepasnya gugus amino $\left(\mathrm{NH}_{2}\right)$ dari asam amino. Nitrogen dikeluarkan dari tubuh dan sisa-sisa ikatan karbon akan diubah menjadi asetil KoA yang nantinya dapat disintesis menjadi trigliserida melalui proses lipogenesis. Hal ini menyebabkan seseorang yang mengkonsumsi banyak protein dalam makanannya dan melebihi jumlah yang dibutuhkan oleh tubuh maka sebagian besar akan disimpan sebagai lemak. ${ }^{25}$ Hasil penelitian ini sejalan dengan penelitian Yi Lin di Eropa tahun 2014 yang menyatakan bahwa terdapat hubungan antara asupan protein dengan obesitas. ${ }^{26}$

Kategori moderasi yang mencakup total lemak, lemak jenuh, kolestrol, natrium, dan makanan rendah zat gizi seluruhnya menunjukkan perbedaan antara kelompok obesitas dan non obesitas. Asupan lemak jenuh menyumbangkan rendahnya kualitas diet pada kedua kelompok karena asupan lemak jenuhnya tergolong tinggi. Sebanyak $92.9 \%$ remaja non obesitas dan $100 \%$ remaja obesitas memiliki asupan lemak jenuh > 10\% total energi/hari. Asupan lemak jenuh yang tinggi pada kedua kelompok terjadi karena mereka sama-sama lebih banyak mengkonsumsi makanan hewani, seperti daging, jeroan, susu, dan makanan yang diolah dengan cara digoreng yang rata-rata memiliki kandungan lemak jenuh tinggi. Hasil ini sejalan dengan penelitian di Iran tahun 2014 yang menunjukkan bahwa asupan lemak jenuh pada remaja tergolong tinggi atau melebihi kebutuhan. ${ }^{27}$ Sementara asupan lemak total, kolestrol, natrium, dan makanan rendah zat gizi berpengaruh terhadap rendahnya kualitas diet pada kelompok obesitas karena asupannya sangat melebihi rekomendasi. Asupan lemak dan natrium yang tinggi berkaitan dengan kebiasaan konsumsi makanan cepat saji pada remaja obesitas dalam penelitian ini. Hasil ini sejalan dengan sebuah penelitian di US tahun 2001 yang menunjukkan bahwa terdapat hubungan yang signifikan antara konsumsi makanan cepat saji dengan peningkatan asupan energi dan asupan lemak. ${ }^{14}$ Penelitian lain yang melibatkan anak-anak dan remaja di negara yang sama tahun 2004 juga menunjukkan hal serupa yaitu remaja yang mengkonsumsi makanan cepat saji memiliki total asupan energi, lemak, karbohidrat lebih tinggi dibandingkan dengan yang tidak mengkonsumsi makanan cepat saji. ${ }^{15}$ Sementara, hubungan asupan natrium dengan tingginya asupan makanan cepat saji ditunjukkan pada penelitian di Australia tahun 2010, dimana makanan cepat saji merupakan salah satu makanan yang memiliki kandungan natrium yang tinggi. ${ }^{28}$ Makanan cepat saji, misalnya fried chicken dalam satu sajian mengandung $287.75 \mathrm{Kal}$, $15.32 \mathrm{~g}$ lemak, $660.14 \mathrm{mg}$ natrium, dan $0 \mathrm{~g}$ serat yang artinya konsumsi satu jenis makanan cepat saji satu kali dalam sehari saja sudah memenuhi $13.6 \%$ kebutuhan energi, 6.5\% kebutuhan lemak, dan $27.5 \%$ kebutuhan natrium yang belum ditambah dengan asupan cepat saji lain yang dikonsumsi bersamaan dan asupan lainnya dalam sehari, sementara remaja obesitas biasanya mengkonsumsi 3 jenis makanan cepat saji dalam satu kali waktu makan. ${ }^{29}$ Makanan cepat saji juga berdampak pada peningkatan asupan makanan rendah zat gizi seperti dalam penelitian di Brazil tahun 2011. ${ }^{30} \mathrm{Hal}$ tersebut sesuai dengan penelitian ini, dimana asupan makanan rendah zat gizi juga lebih tinggi pada kelompok obesitas dan salah satu jenisnya mencakup makanan cepat saji (fastfood) karena merupakan makanan yang tinggi energi, namun rendah serat. Selain fastfood, softdrink juga termasuk dalam makanan rendah zat gizi karena dalam $340 \mathrm{ml}$ regular cola mengandung energi sebanyak 140-150 Kal, 39-41 g gula. ${ }^{31}$ Minuman soda diyakini memiliki kontribusi besar terhadap kejadian kelebihan berat badan dan obesitas. Remaja yang mengkonsumsi minuman soda memiliki asupan energi yang lebih tinggi dikarenakan pemanis buatan yang ditambahkan untuk menambah rasa manis pada minuman soda mencapai $7-14 \%$ sehingga meningkatkan asupan energi remaja. ${ }^{32}$

Skor kategori keseimbangan keseluruhan menunjukkan adanya perbedaan antara kedua kelompok. Kelompok non obesitas memiliki nilai 
yang lebih baik pada rasio makronutrien (karbohidrat : protein : lemak), sementara pada rasio asam lemak (PUFA : MUFA : SFA) sama-sama memiliki nilai yang rendah walaupun kenyataannya sebagian besar remaja pada kedua kelompok memiliki keseimbangan yang rendah. Rasio makronutrien pada kelompok obesitas sebanyak 91.1\% dan $69.7 \%$ pada kelompok non obesitas menunjukkan keseimbangan yang rendah, ditunjukkan dengan proporsi lemak yang mencapai $>30 \%$, proporsi protein $<8 \%$ atau $>17 \%$, dan karbohidrat $<50 \%$ atau $>70 \%$. Hasil ini sejalan dengan penelitian yang dilakukan pada remaja di Bahrain dan Saudi Arabia yang menemukan bahwa keseimbangan antara konsumsi sumber karbohidrat, lemak, dan protein masih rendah karena lemak yang mencapai $>36 \%$, protein $<12 \%$, dan karbohidrat $<55 \%$. ${ }^{33}$ Skor rasio asam lemak (PUFA : MUFA : SFA) dalam kualitas diet pada kedua kelompok juga sama-sama menunjukkan nilai yang rendah. Hal ini terjadi karena kebutuhan SFA seharusnya adalah $<7 \%$ total energi/hari, namun asupan SFA pada kedua kelompok memiliki nilai rata-rata yang tinggi, yaitu $19.4 \%$ total energi/hari pada kelompok obesitas dan $16.4 \%$ total energi/hari pada kelompok non obesitas. Sementara pada asupan PUFA yang seharusnya $<10 \%$ total energi/hari dan MUFA sebesar $<15 \%$ total energi/hari justri tidak ada yang mencapai kebutuhan pada kedua kelompok. Asupan PUFA hanya sebanyak $8.2 \%$ pada kelompok obesitas dan $6.4 \%$ pada kelompok non obesitas, sedangkan asupan MUFA sebesar $5.1 \%$ pada kelompok obesitas dan $4.7 \%$ pada kelompok non obesitas. Asupan SFA yang tinggi membuat skor rasio asam lemak menjadi rendah. Proporsi antara PUFA, MUFA, dan SFA seharusnya lebih banyak di MUFA, PUFA, kemudian SFA sehingga bisa didapatkan rasio asam lemak melalui $\mathrm{P} / \mathrm{S}$ dan $\mathrm{M} / \mathrm{S}$ yang baik yaitu antara 0.8-1.7 untuk keduanya. Asupan SFA yang lebih tinggi dibanding PUFA dan MUFA pada kedua kelompok terjadi karena mereka sama-sama lebih banyak mengkonsumsi makanan yang rata-rata memiliki kandungan SFA tinggi dibandingkan makanan dengan PUFA dan MUFA yang tinggi, seperti alpukat, ikan dan produk dari kacang-kacangan terutama kacang kedelai. Hasil ini sejalan dengan penelitian di Iran tahun 2014 yang menunjukkan bahwa asupan SFA pada remaja tergolong tinggi atau melebihi kebutuhan, sementara asupan PUFA dan MUFA tergolong rendah. ${ }^{27}$ Asupan SFA yang tinggi pada remaja dapat memberikan efek yang negatif. Kelebihan asupan SFA dapat mengakibatkan peningkatan jumlah lemak tubuh, karena sebagian besar lemak jenuh besar disimpan di jaringan adipose. ${ }^{34}$ Lemak jenuh juga merupakan penyebab utama peningkatan kolesterol dan kolesterol-LDL, karena peningkatan lemak jenuh akan menurunkan aktivitas ambilan LDL oleh reseptor LDL dan menurunkan ekskresi kolesterol dalam pembuluh darah, selain itu lemak jenuh meningkatkan produksi LDL, sehingga asupan lemak jenuh yang tinggi menjadi risiko terjadinya dislipidemia pada individu obesitas. ${ }^{35}$

Aktivitas fisik pada remaja obesitas dan non obesitas menunjukkan adanya perbedaan. Hasil pengukuran aktivitas fisik dalam penelitian ini adalah sebanyak $73.2 \%$ remaja obesitas memiliki aktivitas fisik yang rendah, sementara hanya ada $23.2 \%$ remaja non obesitas yang memiliki aktivitas rendah. Di sisi lain, terdapat $25 \%$ remaja non obesitas memiliki komponen aktivitas fisik yang tinggi dan $51.8 \%$ remaja non obesitas memiliki komponen aktivitas fisik sedang. Rendahnya aktivitas fisik pada pada remaja obesitas dalam penelitian ini berkaitan dengan perilaku sedentary lifestyle. Remaja obesitas lebih banyak melakukan aktivitas seperti menonton televisi, bermain handphone atau laptop, dan tiduran disertai mendengarkan lagu. Rata-rata mereka menghabiskan waktu 4-5 jam di luar jam sekolah dalam melakukan kegiatan sedentary seperti di atas dibandingkan kelompok non obesitas yang menghabiskan waktu 1-2 jam. Hasil ini sejalan dengan berbagai penelitian yang menunjukkan adanya hubungan aktivitas fisik dengan kejadian obesitas remaja. ${ }^{36}$ Sementara lebih tingginya aktivitas fisik pada remaja non obesitas disebabkan karena keikutsertaan mereka dalam kegiatan ekstrakulikuler, terutama basket dan futsal yang merupakan jenis kegiatan dengan komponen aktivitas tinggi, sedangkan remaja non obesitas lebih banyak mengikuti kegiatan ekstrakulikuler di bidang non olahraga, seperti paduan suara dan informatika yang termasuk kategori aktivitas rendah.

Berdasarkan hasil uji chi square, kualitas diet dan aktivitas fisik sama-sama berhubungan dengan status obesitas pada remaja. Kualitas diet yang berhubungan dengan obesitas digambarkan dari hasil penilaian empat kategori kualitas diet, yaitu variasi, kecukupan, moderasi, dan keseimbangan keseluruhan. Kelompok obesitas memiliki variasi asupan sumber makanan yang tinggi. Pada kategori kecukupan, kelompok obesitas memiliki asupan sayur, buah, serat, dan mikronutrien yang rendah, sementara asupan energi, kelompok makanan pokok, dan protein tergolong tinggi. Kategori moderasi menunjukkan kelompok obesitas memiliki asupan lemak, lemak jenuh, kolestrol, natrium, dan makanan rendah zat 
gizi yang tinggi dan dari kategori keseimbangan keseluruhan, kategori obesitas memiliki keseimbangan makronutrien dan asam lemak yang rendah. Selain itu, aktivitas fisik juga menunjukkan adanya hubungan dengan status obesitas remaja. Aktivitas fisik yang berperan dalam terjadinya obesitas adalah aktivitas fisik yang rendah yang digambarkan dengan perilaku sedentary lifestyle yang dilakukan oleh remaja obesitas.

Hasil uji multivariat menunjukkan kualitas diet dan aktivitas fisik yang rendah masing-masing berisiko 10.4 dan 7.2 kali lebih besar untuk mengalami obesitas. Kualitas diet rendah menunjukkan asupan makanan pada remaja tidak sesuai dengan rekomendasi, padahal keseimbangan dan pemenuhan zat gizi yang sesuai dengan rekomendasi sangat dianjurkan, sementara aktivitas fisik yang rendah menunjukkan minimalnya pergerakan yang dilakukan oleh seseorang, baik dari jenis maupun intensitasnya. Penerapan kualitas diet rendah dan aktivitas fisik rendah pada subjek menjadi sebuah faktor gaya hidup yang berlangsung lama sehingga berdampak terjadinya obesitas pada periode tersebut. Keduanya merupakan kategori yang berperan dalam keseimbangan energi positif, dimana keseimbangan energi positif dapat terjadi kerena tiga hal, yaitu (1) peningkatan asupan dan tidak terjadi pengeluaran energi, (2) terjadi penurunan pengeluaran energi, tanpa peningkatan asupan, dan (3) peningkatan asupan dan rendahnya pengeluaran energi. ${ }^{6,7}$ Obesitas yang terjadi pada remaja dalam subjek penelitian ini disebabkan oleh adanya peningkatan asupan dan rendahnya pengeluaran energi. Kualitas diet rendah pada remaja obesitas sebagai tanda adanya peningkatan asupan dan aktivitas fisik yang rendah menjadi sebab rendahnya pengeluaran energi. Apabila asupan seseorang sangat melebihi kebutuhan sementara aktivitas fisiknya rendah, maka yang terjadi adalah asupan yang melebihi kebutuhan tadi akan disimpan oleh tubuh sebagai lemak karena sedikitnya penggunaan energi yang lama-kelamaan dapat menimbulkan obesitas. ${ }^{37}$

\section{SIMPULAN}

Sebagian besar remaja obesitas dan non obesitas memiliki kualitas diet rendah. Kualitas diet yang rendah pada remaja obesitas disebabkan karena tingginya seluruh asupan pada kategori moderasi, rendahnya asupan sayur, buah, serat, dan mikronutrien pada kategori kecukupan, dan keseimbangan makronutrien serta asam lemak yang rendah pada kategori keseimbangan keseluruhan, sementara pada remaja non obesitas lebih disebabkan karena rendahnya asupan pada sebagian besar kelompok makanan dan zat gizi di kategori kecukupan (sayur, buah, protein, serat, dan mikronutrien), asupan lemak jenuh yang tinggi pada kategori moderasi, dan keseimbangan yang rendah pada kategori keseimbangan keseluruhan (makronutrien dan asam lemak). Remaja obesitas lebih banyak yang memiliki aktivitas fisik rendah dibandingkan dengan remaja non obesitas. Remaja dengan kualitas diet rendah dan aktivitas fisik rendah masing-masing memiliki risiko 10.4 dan 7.2 kali lebih besar untuk mengalami obesitas.

\section{SARAN}

Kelompok remaja obesitas dan non obesitas sebaiknya diberikan edukasi atau konseling gizi mengenai kualitas diet yang baik seperti mengurangi makanan tinggi lemak, terutama lemak jenuh dan peningkatan asupan makanan yang tinggi serat dan mikronutrien, serta peningkatan aktivitas fisik, seperti olahraga sebagai tindakan preventif untuk remaja non obesitas dan tindakan kuratif untuk remaja obesitas.

\section{DAFTAR PUSTAKA}

1. Proverawati A. Obesitas dan Gangguan Perilaku Makan pada Remaja. Yogyakarta: Muha Medika; 2010.

2. Sulistyoningsih H. Gizi Untuk Kesehatan Ibu dan Anak. Yogyakarta: Graha Ilmu; 2011.

3. Badan Penelitian dan Pengembangan Kesehatan. Riset Kesehatan Dasar (Riskesdas 2013). Jakarta: Kementerian Kesehatan Republik Indonesia; 2013.

4. Badan Penelitian dan Pengembangan Kesehatan. Riset Kesehatan Dasar (Riskesdas 2010). Jakarta: Kementerian Kesehatan Republik Indonesia; 2010.

5. Badan Penelitian dan Pengembangan Kesehatan. Hasil Riskesdas 2013 Provinsi Jawa Tengah. 2013. Available from URL: http://www.dinkesjatengprov.go.id/. Accessed March 4, 2015.

6. Heird W.C. Parental Feeding Behavior and Children's Fat Mass. The American Journal Of Clinical Nutrition. 2002; 75(3): 451-452.

7. Nugraha GI. Etiologi dan Patofisiologi Obesitas. Dalam: Soegih RR, dan Wiramihardja KK (Editor). Obesitas Permasalahan dan Terapi Praktis. Jakarta: Sagung Seto; 2009. hal. 9-18.

8. Kopelman PG. Obesity as a Medical Problem. Nature. 2000; 404 (6778): 635-643.

9. Wolongevicz DM, Zhu L, Pencina MJ, Kimokoti RW, Newby PK, D'Agostino RB, et al. Diet quality and obesity in women: the Framingham Nutrition Studies. British Journal of Nutrition. 2010; 103(8): 1223-1229.

10. Kim S, Haines PS, Siega-Riz AM, and Popkin BM.. The Diet Quality Index-International (DQI-I) Provides an Effective Tool for Cross-National Comparison of Diet Quality as Illustrated by China 
and the United States. The Journal of Nutrition. 2003; 133(11): 3476-3484.

11. Family Nutrition Program Diet Quality of American by Food Stamp Participation Status: Data from the National Health and Nutrition Examination Survey, 1999-2004. United States Food and Department of Nutrition Agriculture Service, July 2008.

12. Suryaputra K dan Nadhiroh SR. Perbedaan Pola Makan dan Aktivitas fisik antara Remaja Obesitas dengan Non Obesitas. Makara, kesehatan. 2012; 16(1): 45-50.

13. Rosenheck R. Fast food consumption and increased caloric intake: a systematic review of a trajectory towards weight gain and obesity risk. Obesity reviews. 2008; 9(6): 535-547.

14. French SA, Story M, Neumark-Sztainer D, Fulkerson JA, Hannan P. Fast food restaurants use among adolescents: associations with nutrient intake, food choices, and behavioral and psychosocial variables. Int J Obes. 2001; 25(12): 1823-1833.

15. Bowman SA, Gortmaker SL, Ebbeling CB, Pereira MA and Ludwig DS. Effect of Fast Food Consumption on Energy Intake and Diet Quality Among Children In a National Household Survey. Journal of The American Academy of Pediatrics. 2004; 113(1): 112-118.

16. Malik VS, Schulze MB, and Hu FB. Intake of sugarsweetened beverages and weight gain: a systematic review. The American Journal of Clinical Nutrition. 2006; 84(2): 274-288.

17. Harrington $S$. The role of sugar-sweetened beverage consumption in adolescent obesity: a review of the literature. J Sch Nurs. 2008; 24(1): 3-12.

18. Zalilah MS, Khor GL, Mirnalini K, Norimah AK, Ang M. Dietary intake, physical activity and energy expenditure of Malaysian adolescents. Singapore Medical Journal. 2006; 47(6): 491-498.

19. Tur JA, Romaguera D and Pons A. The Diet Quality Index-International (DQI-I): is it a useful tool to evaluate the quality of the Mediterranean diet? British Journal of Nutrition. 2005; 93(3): 369-376.

20. Florence MD, Asbridge M, and Veugelers PJ. Diet Quality and Academic Performance. Journal of School Health. 2008; 78(4): 209-215.

21. World Health Organization. Global Physical Activity Surveillance. 2010. Available from: http://www.who.int/chp/steps/GPAQ/en/index.htm 1. Accessed February 5, 2015.

22. Guidelines for Data Processing and Analysis of the International Physical Activity Questionnaire (IPAQ)- Short and Long Forms. November 2005. Diunduh

dari http://www.ncbi.nlm.nih.gov/pmc/articles/PMC27 44347/ diakses pada tanggal 18 Februari 2015.

23. Aprianthi Wayan. Kajian Konsumsi Serat pada Remaja di SMA Negeri 1. [Skripsi]. Kupang :Universitas Nusa Cendanat. 2009.
24. Thompson JL, Manore MM, Voughan LA. Science of Nutrition. $2^{\text {nd }}$ ed. USA: Pearson Education Inc.; 2011. p. 126-7, 345.

25. Mahan LK, Stump SE, and Raymond JL. Krause's Food and The Nutrition Care Process Thiteenth Edition. USA: Elesevier; 2012. Hal: 410-421.

26. Lin Y, Mouratidou T, Vereecken C, Kersting M, Bolca S, Moraes AC, et al. Dietary animal and plant protein intakes and their associations with obesity and cardio-metabolic indicators in European adolescents: the HELENA cross-sectional study. Nutrition Journal. 2015; 14(10).

27. Takalloo SM, Mirmiran P, Esfahani FH, Azizi F. Dietary Fat Intake and Its Relationship with Serum Lipid Profiles in Tehranian Adolescents. Journal of Food and Nutrition Research. 2014; 6(2): 330-334.

28. Webster JL., Dunford EK, and Neal BC. A systematic survey of the sodium contents of processed foods. Am J Clin Nutr. 2010; 91: 413420.

29. Novitasari. Kebiasaan Mengonsumsi Western Fast Food Pada Remaja SMU yang Berstatus Gizi Normal dan Obese di Kota Bogor. [skripsi]. Jurusan Gizi Masyarakat dan Sumberdaya Keluarga, Fakultas Pertanian, Institut Pertanian Bogor. 2005.

30. Monteiro CA, Levy RB, Claro RM., Castro IR, and Cannon G. Increasing consumption of ultraprocessed foods and likely impact on human health: evidence from Brazil. Public Health Nutr.2011; 14: 5-13.

31. Tufts University Health and Nutrition Letter. 2011. "Hard News About Soft Drinks". http://search.proquest.com/.

32. Sufiati B. Dampak negatif konsumsi junk-food. Simposium fast food; 13 April 2003; Semarang.

33. Gharib N, Rasheed P. Energy and Macronutrient Intake and Dietary Pattern Among School Children in Bahrain: a Cross-Sectional Study. Nutritional Journal. 2011; 10(62).

34. Juturu V. Trans Fatty Acids and Cardiometabolic Syndrome. AOC Press. Urbana: 2009

35. Fatimah ZB, Saifuddin S, Rahayu I. Pola Konsumsi Terhadap Kejadian Obesitas Sentral pada Pegawai Pemerintahan di Kantor Bupati Kabupaten Jeneponto. 2012. Skripsi Sarjana. Fakultas Kesehatan Masyarakat. Universitas Hasanuddin. Makassar

36. Stankov I, Olds T, Cargo M. Overweight and obese adolescents: what turns them off physical activity?. International Journal of Behavioral Nutrition and Physical Activity. 2012; 9: 53.

37. Steffen N, S B. Infant Weight Gain and Childhood Overweight Status in a Multicenter, Cohort Study. Journal of the American Academy of Pediatrics. 2002; 109: 109-94. 